\title{
BITWA O SŁOWA
}

\section{ANDRZEJ WALICKI. \\ OD PROJEKTU KOMUNISTYCZNEGO \\ DO LIBERALNEJ UTOPII}

Łukasz Pawłowski

Uniwersytet Warszawski

Mówiąc w kilku słowach, jest to praca o... kilku słowach. Andrzej Walicki od lat publikuje książki, eseje i artykuły, starając się rozjaśnić znaczenie ważnych, a jego zdaniem błędnie rozumianych pojęć. Należą do nich „komunizm” i „antykomunizm”, „lewicowość” i „prawicowość”, „socjaldemokracja” oraz ,liberalizm” wraz z towarzyszacymi mu rozmaitymi przedrostkami i przymiotnikami.

Od projektu komunistycznego do liberalnej utopii to zbiór tekstów Walickiego, publikowanych na przestrzeni lat, m.in. w „Gazecie Wyborczej”, Tygodniku Idei „Europa” czy „Przeglądzie Politycznym”. Specjalnie do tego tomu Autor przygotował tylko jeden, ale za to najdłuższy, ponadstustronicowy esej, Cayy możliny jest liberalizm lewicowy?. W książce nie znajdziemy zatem myśli z innych prac nieznanych. A jednak zestawienie wszystkich artykułów w jednym tomie zwiększa siłę zawartych w nich argumentów i pokazuje intelektualną konsekwencję Autora, choć dzieje się to kosztem nieuchronnych, niekiedy drażniących powtórzeń.

Nie zmienia to faktu, że książka Andrzeja Walickiego to zbiór bardzo dobrze napisanych esejów z przekonująco wyłożonymi racjami, którym wciąż nie poświęca się w polskiej debacie publicznej wystarczającej uwagi. Nie chodzi bynajmniej o to, by z Walickim w każdej kwestii należało się bezwzględnie zgodzić. Ale definicje owych kilku terminów, kluczowych dla jego myślenia o polskiej historii i polityce, powinny być w dyskusji ważnym punktem odniesienia. Prześledźmy je po kolei.

\section{/// Komunizm}

Zmagania z tym pojęciem zaczyna Autor od rewolucji rosyjskiej. Wraca - jak sam przyznaje - do argumentów wyłożonych na łamach książki Marksizm i skok do królestwa wolności i dowodzi, że komunizm w wydaniu 
bolszewickim nie był „czymś swoiście, organicznie rosyjskim, niemającym nic wspólnego z cywilizacją zachodnią" (s. 3-4). Powołując się na wybrane pisma Marksa, Engelsa i Lenina, Walicki przekonuje, że zasadnicze dla bolszewików hasła odgórnej organizacji społeczeństwa, ścisłej kontroli państwowej oraz likwidacji wymiany rynkowej i zastapienia jej bezpośrednią wymiana pracy na konkretne produkty stanowiły rdzeń idei Marksowskich, nie ich wypaczenie.

Likwidacja pieniądza, twierdzi Walicki, miała w opinii Marksa doprowadzić do zniesienia „anarchii rynku”. A dzięki ustalanemu odgórnie, na poziomie państwowym, i wprowadzanemu z żelazną konsekwencją profilowi produkcji gospodarka komunistyczna miała zachować pożądana wydajność. Marks chciał tym samym osiagnaćć dwa cele - wyzwolić nowe społeczeństwo od charakterystycznej dla kapitalizmu „tyranii pieniądza” i jednocześnie utrzymać efektywność kapitalistycznego modelu produkcji, którego najpełniejszą formę znajdował w organizacji pracy nowoczesnej fabryki. A zatem, kiedy Lenin określał państwo komunistyczne mianem „jednego biura" i ,jednej fabryki” (s. 15), nie tylko nie sprzeciwiał się postulatom Marksa, lecz dawał wyraz determinacji w dazzeniu do wprowadzenia ich w życie. Ideałem było społeczeństwo funkcjonujące niczym wielki zakład produkcyjny, obywający się jednak bez wymiany pieniężnej.

Oczywista klęska tego modelu gospodarczego bardzo szybko zmusiła przywódcę rewolucji radzieckiej do odwrotu i wprowadzenia Nowej Polityki Gospodarczej (NEP). Jak dowodzi Walicki, zgoda na NEP nie była jednak oznaką zmiany poglądów Lenina, a jedynie chwilowym odwrotem pozwalającym na konsolidację władzy na innych frontach. Ten upokarzajacy dla rewolucjonistów krok wstecz miał dać im moment wytchnienia przed kolejną próbą realizacji komunistycznej utopii.

Śmierć Lenina w 1924 roku pokrzyżowała te plany, a polityka jego następcy w oczach dawnych towarzyszy pokroju Trockiego była zdrada rewolucyjnych ideałów. To przecież za rządów Stalina „zrehabilitowano tradycyjne wartości”, takie jak rodzina, hierarchia społeczna czy naród (s. 35). Walicki przekonuje więc nie tylko, że komunizm bolszewicki nie był rosyjskim wypaczeniem myśli Marksa. Dowodzi również, że w pewnym sensie komunizm skończył się w ZSRR nie w roku 1991 w wyniku rozpadu kraju, lecz sześć dekad wcześniej wraz ze stabilizacją władzy Stalina.

Reżim stalinowski był bez wątpienia reżimem totalitarnym. Zdaniem Walickiego nie był już jednak reżimem komunistycznym ${ }^{1}-\mathrm{w}$ sensie

\footnotetext{
1 Autor twierdzi nawet, że był to „reżim znajdujący się w pół drogi między socjalizmem a kapitalizmem, zdolny do odchylenia w obu kierunkach" (s. 35).
} 
rzeczywistego dążenia do realizacji komunistycznej utopii - mimo że hasła komunistyczne nadal stanowiły podstawę jego legitymizacji.

\section{/// Totalitaryzm}

Wydawać by się mogło, że referowane wyżej wywody na temat rewolucji rosyjskiej wpisują się w przebrzmiała już dyskusję dotyczącą zasadności obwiniania Marksa o bolszewickie wypaczenia. Dyskusji, która niewiele wnosi do sporów o polską historię najnowszą czy tym bardziej o polski model liberalizmu. A jednak, patrząc z perspektywy całej książki, dostrzeżemy, że rozdział ten pełni w niej ważną rolę, pozwala bowiem lepiej rozumieć sposób myślenia Walickiego na innych polach.

Jego interpretacja dziejów komunizmu radzieckiego ma niebagatelne znaczenie choćby dla sposobu rozumienia powojennych wydarzeń w Polsce. Wbrew powszechnym interpretacjom za kluczowy moment degrengolady ustroju PRL uważa Autor nie czerwiec roku 1989 czy sierpień 1981, lecz październikową odwilż 1956 roku. Ówczesna zmiana władzy i celów, jakie sobie owa władza stawiała, stanowiła przesilenie, po którym - jak powiada Walicki za Zbigniewem Pełczyńskim - „polska droga do komunizmu" stała się drogą od komunizmu (s. 112).

Przełomowe znaczenie tego okresu polegało na porzuceniu przez władze aspiracji totalitarnych, rozumianych jako chęć kontrolowania wszystkich sfer życia obywateli i dążenie do stworzenia nowego, komunistycznego człowieka. Po roku 1956 PZPR zachowała co prawda monopol na władzę polityczną, ale zrezygnowała z prób wprowadzenia nadzoru totalnego, wspieranego „terrorem i niebywała presją ideologiczna”. Instytucje naukowe i kulturalne zyskały, zdaniem Walickiego, niespotykana autonomię, czego dowodem było nie tylko odejście od zasad socrealizmu w filmie, literaturze czy sztukach plastycznych, ale także... jego osobisty sukces zawodowy ${ }^{2}$.

W czasach stalinizmu prześladowany $\mathrm{m}$.in. ze względu na pochodzenie klasowe i niechęć do angażowania się w życie „kolektywu studenckiego”, Walicki nie tylko miał ograniczone możliwości realizacji zawodowej, ale na skutek wymaganej odeń, regularnej samokrytyki przeszedł załamanie nerwowe i był leczony psychiatrycznie. Dopiero przemiany październikowe otworzyły mu droge do kariery naukowej - otrzymał kilka zawodowych propozycji, a jego prace zaczęły być publikowane.

Pozytywnej oceny tych przeobrażeń nie zmienia w opinii Autora nawet późniejsze zaostrzenie kursu władz, krytyka rewizjonizmu i uciszenie

2 Zob. Walicki 1993. 
reformistycznych środowisk skupionych m.in. wokół tygodnika „Po prostu". To diagnoza skrajnie odmienna od oceny chociażby Leszka Kołakowskiego, który W głównych nurtach marksiz̨mu twierdził, że „tak zwany «październik polski», czyli objęcie władzy przez Gomułkę i jego ekipę, nie był bynajmniej poczattiem społecznej czy kulturalnej odnowy albo «liberalizacji», ale wręcz przeciwnie, początkiem jej końca” (Kołakowski 2009: 459).

Skąd ta różnica? Rewizjoniści pokroju Kołakowskiego liczyli na możliwość oddziaływania politycznego na władze, mimo że zdaniem Walickiego oczekiwanie rewolucji w tej dziedzinie było w ówczesnych warunkach wyrazem jeśli nie naiwności, to co najmniej niczym nieuzasadnionego optymizmu. Rozczarowanie rewizjonistów wynikało więc z tego, że choć byli głównymi inicjatorami zmian politycznych, nie stali się ich beneficjentami. W wypadku większości ludzi - „pragnących głównie poszerzenia zakresu wolności osobistej, a nie wolności jako politycznej partycypacji”" (Walicki 2013: 76) - było dokładnie odwrotnie. Dla tej grupy - do której należał także Andrzej Walicki - zdobycze Października okazały się trwałe.

Ustrój polityczny PRL zaczął więc, zdaniem Walickiego, kruszeć na długo przed obradami Okragłego Stołu czy wcześniejszym niemal o dekadę „karnawałem Solidarności”. Takie postawienie sprawy, do pewnego stopnia uzasadnione historycznie, prowadzi jednak Autora do radykalnych twierdzeń dotyczących dalszych losów systemu. We wstępie do książki czytamy na przykład, że „realny socjalizm” w PRL „zmarł w gruncie rzeczy śmiercią naturalna”, a „mobilizacja sił antysystemowych była nie tyle przyczyna, co rezultatem obumierania ustroju" (s. XXV). To w moim przekonaniu zbyt daleko posunięta teza, która nie tylko dramatycznie upraszcza proces rozpadu systemu, ale także umniejsza ogromne poświęcenie $\mathrm{i}$ wysiłek tysięcy ludzi zaangażowanych w walkę $\mathrm{z}$ nietotalitarnym już, to prawda, lecz wciąż bardzo silnym aparatem władzy.

Tymczasem w narracji Walickiego opozycja popaździernikowa przypomina plankton niesiony na fali gomułkowskiej odwilży. Autor ma rację, twierdząc, że na poziomie systemowym ustrój zmienił swój charakter, ale myli się, twierdząc, że było to zdarzenie w prostej linii prowadzące do rozpadu PRL. Tę perspektywę w analizach historycznych należy uwzględnić, ale z pewnościa proponowanego wyjaśnienia nie wolno uznać za wyczerpujące. Nietrudno przecież znaleźć przykłady ustrojów autorytarnych, które mimo braku solidnej podstawy ideologicznej utrzymywały się latami. Nie sądzę, by ktokolwiek na Kubie wierzył jeszcze, że reżim braci Castro zmierza do realizacji marksowskiej utopii, stworzenia „,nowego człowieka” i lepszego świata. W wielu innych państwach regionu autorytarne ustroje 
również trwały lub trwają w najlepsze, choć ich wyłącznym celem jest trwanie właśnie, a nie wdrażanie w życie jakichkolwiek ideałów. A zatem wypłukanie systemu z ideologicznej wiary nie musi - wbrew tezom Andrzeja Walickiego - prowadzić nieuchronnie do jego upadku. Potrzebne są do tego ogromne poświęcenie i odwaga wielu ludzi. Skąd się tacy ludzie biora, jak działają i dlaczego odnoszą sukces? Systemowe spojrzenie proponowane przez Autora nic nam na ten temat nie mówi.

\section{/// Lewica i prawica}

Jednostronność powyższej opinii Walickiego stoi ponadto w wyraźnej sprzeczności z jego wezwaniem do większej wrażliwości na niuanse chociażby przy formułowaniu ocen dziedzictwa PRL. Apel ten kieruje on wielokrotnie na kartach omawianej książki do polskiej prawicy, która jego zdaniem ze swoiście pojmowanego antykomunizmu uczyniła podstawowa zasadę myślenia. Antykomunizm to specyficzny, bo obiektem bezkompromisowego sprzeciwu czyni cały okres Polski Ludowej, uznając go przy okazji za okupację i wyrwę w historii kraju, oddzielającą II i III Rzeczpospolita.

W korespondencyjnych debatach z tymi, których uznawał za przedstawicieli prawej strony sceny politycznej, Walicki powraca więc niejednokrotnie do wyjaśnień znaczenia terminu „komunizm”, a także podkreśla różnice między polską rzeczywistością przed i po Październiku roku 1956. Nieprzejednane stanowisko prawicy doprowadziło w jego opinii nie tylko do stygmatyzacji znacznej części elit politycznych związanych z poprzednimi władzami, ale także do całkowitego odrzucenia wszelkich ideałów lewicowych, niezależnie od ich związków z realnie istniejącym w naszym kraju socjalizmem.

Polska lewica jest oceniana, zdaniem Walickiego, nie w kategoriach politycznych, lecz moralnych - jako z gruntu zła - co dyskwalifikuje jej przedstawicieli jako potencjalnych partnerów do rozmowy, pogłębia istniejące podziały ideologiczne oraz prowadzi do wypaczenia pojęć fundamentalnych dla polityki. Wszelką lewicę utożsamia się w Polsce z błędnie pojmowanym komunizmem, prawica zaś definiuje się w opozycji do stworzonego przez sama siebie i na własne potrzeby wroga.

Źródeł tego stanu rzeczy upatruje Walicki już w postawach opozycji sprzed roku 1989, która władze PRL-owskie definiowała nie w kategoriach politycznego przeciwnika, lecz moralnego wroga. Mówiąc o Solidarności, Walicki twierdzi, że:

była to wielka krucjata, ćwiczenie się w radykalizmie w demonizowaniu przeciwnika i w odrzucaniu dialogu z nim. Normalna wojna może 
jeszcze wyrabiać szacunek dla drugiej strony, ale wojna moralna, totalny bojkot, bezwarunkowa konfrontacja wymagała napięcia nienawiści, pogardy, umiejętności dyskontowania ustępstw bez odwzajemnienia i kwitowania. Tak widać być musiało, skoro chodziło o wojnę moralną właśnie, o całkowitą delegitymizację strony przeciwnej”. (s. 274)

To kolejna, bardzo kontrowersyjna teza dotycząca historii polskiej transformacji ustrojowej. Walicki zdaje się nie dostrzegać, że wielu działaczy opozycyjnych podjęło polityczny dialog z władza, czego najlepszym wyrazem były chociażby ustalenia Okragłego Stołu. Ustalenia, które zostały podtrzymane mimo rozpadu kolejnych państw demokracji ludowej, a tym samym dramatycznego osłabienia obozu rządzącego. Czy opozycja powstrzymałaby się przed całkowitym pogrązeniem przeciwnika, gdyby w relacjach $z$ nim kierowała się jedynie standardami moralnymi a nie politycznymi, jak twierdzi Walicki?

Przyjąwszy poglądy Autora, jeszcze większe trudności napotkamy, próbując wyjaśnić inne ważne wydarzenia polityczne pierwszej połowy lat 90 . Mam tu na myśli choćby uszanowanie demokratycznego zwycięstwa SLD w wyborach parlamentarnych roku 1993 - zaledwie cztery lata po odsunięciu od władzy PZPR - oraz uznanie dla sukcesu Aleksandra Kwaśniewskiego w wyborach prezydenckich w 1995 roku. Ponadto, jeśli postkomunistom powszechnie odbierano moralne prawo do pełnienia funkcji publicznych, jak wyjaśnić uchwalenie konstytucji w roku 1997 z Aleksandrem Kwaśniewskim jako przewodniczącym Komisji Konstytucyjnej? Gdyby - jak zdaje się sądzić Walicki - większość polityków opozycyjnych traktowała siły postkomunistyczne wyłącznie w kategoriach moralnych, polska scena polityczna przynajmniej od 1993 roku powinna być areną nie walki politycznej, lecz totalnej wojny na wyniszczenie. A tak po prostu nie było.

Walicki ma jednak niewątpliwie rację, kiedy twierdzi, że na skutek doświadczeń z realnym socjalizmem dyskredytacji uległy w Polsce ideały lewicowe i związane z nimi pojęcia. Socjaldemokrację i lewicę poczęto utożsamiać nie tylko z PRL-em, ale z komunizmem per se, co było równoznaczne $z$ ich odrzuceniem.

\section{/// Neoliberalizm}

To właśnie w tym poplątaniu pojęć Walicki dopatruje się również przyczyn mylnego rozumienia liberalizmu jako doktryny wyłącznie ekonomicznej i stawiającej szeroko rozumianą wolność człowieka niżej od wąsko pojmowanej wolności abstrakcyjnych rynków: 
Grube nieporozumienia co do „liberalizmu”, tak charakterystyczne dla sceny politycznej i potocznego myślenia w naszym kraju, są organicznym wytworem długiej historii grubych nieporozumień co do „komunizmu”, „realnego socjalizmu” i zalecanych sposobów „dekomunizacji”. (s. XXVII) $)^{3}$

I tym razem, podobnie jak w wypadku oceny przemian październikowych, trudno nie przyznać Walickiemu częściowej racji. Czołowy przedstawiciel polskiego neoliberalizmu i główny autor transformacji gospodarczej, Leszek Balcerowicz, wydaje się uznawać wszelkie próby zwiększenia roli państwa w gospodarce za zamach na jednostkową wolność, prowadzący w prostej linii do komunistycznego totalitaryzmu ${ }^{4}$. To pogląd skrajny, ale wciąż silnie obecny w debatach publicznych, w okresie transformacji zaś absolutnie dominujący. Odwołanie się wówczas do sympatii lewicowych czy socjaldemokratycznych wiązało się z wielkim ryzykiem politycznym, a nierzadko było oceniane negatywnie także w kategoriach moralnych. W rezultacie wielu sympatyków lewicy było zmuszonych do poparcia neoliberalnej „terapii szokowej”.

Do dziś zresztą wszelkie postulaty socjalne bywają w Polsce krytykowane jako przejawy roszczeniowości i sowieckiej mentalności mitycznego bomo sovieticus. Diagnoza Walickiego - zgodnie z którą sukces neoliberalizmu wynikał z panującego w Polsce radykalnego antykomunizmu

${ }^{3}$ Jak powiedział Andrzej Walicki w rozmowie z autorem niniejszej recenzji dla tygodnika „Kultura Liberalna”, niechęć do PRL i utożsamienie „realnego socjalizmu” z komunizmem w wypadku części prawicy przybiera formy tak skrajne, że prowadzi do afirmacji... nazizmu jako ideologii historycznie komunistom wrogiej: „Dominujące w Polsce stanowisko, zgodnie z którym wszystko, co nawet trąci PRL, musi być z miejsca złe, a także nihilistyczny stosunek do dorobku Polaków z tego okresu - nie chodzi bynajmniej o dorobek władz czy państwowych instytucji, ale ludzi - prowadzą do prawdziwych kuriozów. [...] Na przykład z faktu, że Hitler był przeciwnikiem bolszewików oraz przesłanki, jakoby PRL była największym złem, wyprowadza się wniosek, że w latach 30. lepiej było sprzymierzyć się z nazistami, niż z nimi walczyć. W rezultacie dochodzi do tego, że jakaś grupa ludzi idzie na grób Witolda Pileckiego, bohatera polskiego ruchu oporu, ze swastykami na ramieniu. To przechodzi moje pojęcie”. („Radykalizacja prawicy przyspiesza” - z Andrzejem Walickim rozmawiaja Jarosław Kuisz i Lukasz Pawłowski, Kultura Liberalna, nr 254 (46/2013) z 19 listopada 2013 r.; http://kulturaliberalna.pl/2013/11/19/andrzej-walicki-radykalizacjaprawicy-przyspiesza-wywiad-miesiaca/).

4 „Socjaliści praktycy, począwszy od Lenina, uznali, że lepszego człowieka, a w każdym razie lepsze społeczeństwo, da się stworzyć, gdy się wymorduje lub zastraszy jego gorsza część (burżuazję) i zniszczy przypisywane mu instytucje”. Zob. Balcerowicz 2009: 49.

${ }^{5}$ Najbardziej chyba znaną tego rodzaju postacią - której polityczną biografię omawia Walicki w jednym z zawartych w zbiorze artykułów - był Jacek Kuroń. 
- wydaje się zatem przynajmniej częściowo słuszna. Z pewnością nie jest jednak wystarczająca. Jak bowiem za jej pomocą wyjaśnić socjaldemokratyczne postulaty polskiej prawicy, reklamowane hasłami „Polski solidarnej” i przeciwstawiane właśnie „Polsce liberalnej”? Partie prawicowe na poziomie retorycznym pozostaja skrajnie antykomunistyczne (w szerokim znaczeniu tego słowa, obejmującym także całe dziedzictwo PRL), ale jednocześnie posługują się niekiedy językiem tradycyjnej lewicy, podkreślającym znaczenie więzi grupowych, łagodzenia nierówności i poprawy szans najbiedniejszych grup społecznych ${ }^{6}$.

To nie jedyna ułomność argumentacji Walickiego. Jego perspektywa może być zastosowana wyłącznie do byłych krajów demokracji ludowej i w żaden sposób nie tłumaczy, dlaczego sukces neoliberalizmu nie ogranicza się wyłącznie do tego regionu, lecz przynajmniej od lat 80 . XX wieku święci triumfy także na Zachodzie. Na to pytanie w książce nie znajdziemy satysfakcjonującej odpowiedzi. Zdaniem Autora neoliberalizm jest „tylko przejściowym trendem, ściśle związanym z określoną sytuacją historyczną", jaką był upadek komunizmu (s. 208). Trudno to wyjaśnienie uznać za przekonujące choćby dlatego, że neoliberalizm zaczął święcić triumfy ponad dekadę przed upadkiem ZSRR, a dwie i pół dekady po tym wydarzeniu nadal ma się znakomicie. Przyczyn gospodarczych, społecznych i politycznych tego stanu rzeczy jest bardzo wiele i nie sposób opisać ich w tego rodzaju recenzji. Należą do nich bez wątpienia prostota, a tym samym atrakcyjność definicji wolności, jaką proponują neoliberałowie; wpływy grup interesów promujących „rozwiązania wolnorynkowe”; dramatycznie szybki rozwój sektora usług finansowych wymagających łatwego przepływu kapitału; postępująca globalizacja; zmiany demograficzne utrudniające utrzymanie pewnych świadczeń socjalnych wprowadzonych w czasie, gdy struktura wiekowa społeczeństwa była odmienna itd.

A zatem i w tym wypadku diagnozę Walickiego, upatrującą źródeł popularności neoliberalizmu w Polsce w mylnie pojmowanym antykomunizmie, traktować należy jako głos w dyskusji, ważny, ale bynajmniej nierozstrzygający.

\footnotetext{
${ }^{6}$ Pomijam w tym wypadku fakt, że często tym hasłom towarzyszą postulaty obniżenia podatków i deregulacji wybranych obszarów rynku, ponieważ tematem niniejszej recenzji nie jest spójność programowa polskich partii politycznych.

7 Cudzysłów w tym miejscu jest wyrazem przekonania, że rynek wolny w rzeczywistości nigdy nie istniał, a rozwiązania opatrywane tym mianem są bardzo często podejmowane przez instytucje państwowe w interesie określonych grup społecznych, a nie sił rynkowych.
} 


\section{/// Liberalizm}

Szczególnie ciekawym produktem zmagań Autora z neoliberalizmem jest wspomniany już bardzo ciekawy esej napisany specjalnie do tego zbio-

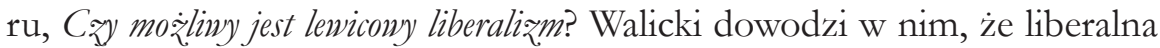
koncepcja wolności nie powinna być redukowana do wolności ekonomicznej. Mało tego, niekiedy wartości liberalne w imię ochrony jednostki moga prowadzić do kolejnych regulacji działań rynku, co nie znaczy bynajmniej, że tak pojmowany liberalizm zagraża stabilności modelu wolnorynkowego. We wspomnianym wywiadzie dla „Kultury Liberalnej” Walicki mówi:

Liberalizm to jest wielka rodzina różnych koncepcji, ale bardzo dla mnie szlachetną tradycja jest ewolucja liberalizmu, która nastapiła od Milla aż do 30 „chlubnych lat”, czyli trzech dekad od końca wojny do połowy lat 70. XX wieku. Nawiasem mówiąc, był to jednocześnie złoty okres kapitalizmu. Nie jest prawda, że w warunkach ówczesnego państwa dobrobytu kapitalizm nie mógł się rozwijać. Ono pomagało, ponieważ kiedy człowiek wie, że w przypadku porażki nie grozi mu całkowity upadek i totalne zgniecenie, więcej jest skłonny zaryzykować. A to stymuluje innowacje. To kłamstwo, że ludzie pod wpływem strachu sa najbardziej wydajni i najlepiej pracuja. Minimum bezpieczeństwa jest potrzebne. (Kuisz, Pawłowski 2013)

Końcowa rozprawa rekonstruuje tę ewolucję myśli liberalnej, a wraz z nią pojęcia wolności. Pokazuje, że w tradycji anglosaskiej wolność bardzo szybko przestała być pojmowana wyłącznie jako niezależność od wpływu państwa - bo czyż w takim wypadku za najbardziej wolne nie należałoby uznać pozbawionych efektywnych władz państw afrykańskich? - ale raczej jako zespół warunków pozwalających na jak najpełniejszą realizację jednostkowych zdolności i pasji. Do ich zapewnienia potrzebni sa nam inni ludzie oraz instytucje regulujące międzyludzkie relacje. Liberalizm nie powinien być zatem, zdaniem Autora, kojarzony z postulatami państwa minimalnego, ale państwa stabilnego i przewidywalnego. W podobnym tonie wypowiadają się także inni polscy intelektualiści przyznający się do sympatii liberalnych, nawet jeśli do poglądów Walickiego w innych kwestiach - choćby jego oceny PRL - jest im bardzo daleko ${ }^{8}$. Takich głosów

\footnotetext{
8 Mam na myśli m.in. Marcina Króla, Jerzego Szackiego, Andrzeja Szahaja czy Pawła Śpiewaka. Zdaniem tego ostatniego „to nieprawda, że mniej państwa to zawsze więcej liberalizmu. Rolę państwa możemy ograniczać dopiero wtedy, kiedy jego podstawy czynią je silnym, stabilnym i zdolnym do egzekwowania przyjętych reguł współżycia. Rolą liberała jest $z$ kolei zadbanie, by te reguły nie były skierowane przeciwko obywatelowi, ale miały
} 
wciąż jest jednak niewiele, dlatego esej Walickiego powinien stanowić ważny punkt odniesienia do dyskusji o istocie liberalizmu.

Wątpliwości budzi jedynie użyta w tym tekście terminologia. Bo czy myśli lepiej przystające do tradycji liberalnej należy opatrywać dodatkowymi przymiotnikami, jak to czyni Autor, pisząc o ,liberalizmie lewicowym"? Przedrostki i przymiotniki lepiej zostawić dla wszelkiej maści specyficznych szkół odwołujących się do tradycji liberalnej, jak choćby „neoliberałów” trafnie nazywanych w tym tomie ,anarchokapitalistami”. Skoro Andrzej Walicki od lat toczy walkę o lepsze rozumienie tego bardzo ważnego dla niego pojęcia, nie powinien godzić się na podobne kompromisy. Tym bardziej że w wielu innych polemikach - z których część omówiono wyżej - wykazuje się o wiele dalej idąca bezkompromisowością.

Ostatni esej pozostawia czytelnika o liberalnych sympatiach intelektualnych z uczuciem podobnym do tego, jakie towarzyszy mu przy lekturze większości zawartych w tym tomie tekstów. Oto stykamy się z interesująca, lewicową wykładnią pewnego pojęcia. Elegancko i klarownie przedstawiona, wykraczająca poza dominujący dyskurs publiczny, wzbudza zainteresowanie i zmusza do poważnej refleksji. Przy bliższej analizie ujawnia jednak pewne braki lub niedopowiedzenia, które nie pozwalają na całkowite zaakceptowanie wywodów Autora. Nie mam wątpliwości, że Walickiego czytać warto, a w sporach o znaczenie owych kilku wymienionych wyżej ważnych pojęć wiele jego argumentów należy przyjąć. Z pewnościa jednak nie należy przyjmować ich bezwarunkowo.

Bibliografia:

// / Balcerowicz L. 2009. Wstę, [w:] Odkerywajac wolność. Przecin znniewoleniu umystów, L. Balcerowicz (red.), Zysk i S-ka, Warszawa.

/// „Grzechy polskiego liberalizmu”, Pawet Śpiewak w rozmowie z. Pawtem Marczenskim i Łukaszem Pawtowskim, „Kultura Liberalna” 2011, nr 120 (17/2011), http://kulturaliberalna.pl/2011/04/25/grzechy-polskiegoliberalizmu-1; dostęp: 09.02.2014.

/// Kołakowski L. 2009. Gtówne nurty marksizmu, Wydawnictwo Naukowe PWN, Warszawa.

na celu ochronę jego uprawnień”. (Grzechy polskiego liberalizmu, Paweł Śpiewak w rozmowie z Pawłem Marczewskim i Lukaszem Pawłowskim, „Kultura Liberalna”, nr 120 [17/2011] z 26 kwietnia 2011 r.). 
/// „Radykalizacja prawicy prayspiesza” - ₹. Andrzejem Walickim rozmawiaja Jarostaw Kuisz i i ukasz Pawtowski, „Kultura Liberalna” 2013, nr 254 (46/2013), http://kulturaliberalna.pl/2013/11/19/andrzej-walicki-radykalizacjaprawicy-przyspiesza-wywiad-miesiaca; dostęp: 09.02.2014.

/// Walicki A. 1993. Spotkania z Mitoszem, [w:] Zniewolony umyst po latach, A. Walicki, Czytelnik, Warszawa.

/// Walicki A. 2013. Od projektu komunistycznego do neoliberalnej utopii, Universitas, Kraków. 